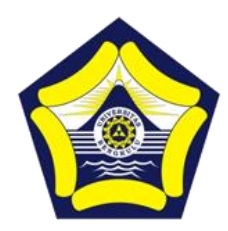

\title{
Improving Learning Outcomes Of Students In Junior High School Number 1 Bengkulu City With Online Learning Model Through Cloud X Application
}

\author{
Lilia Gina Febrila ${ }^{1}$, Hanifah ${ }^{2, *}$ \\ Mathematics Education, Bengkulu University, Indonesia \\ *Email: hanifah@unib.ac.id
}

DOI: https://doi.org/10.33369/bjset.2.1.1-7

\begin{abstract}
The research aims to determine how to implement an online learning model to increase learning outcomes of learners. This type of research is class action research (PTK). The subject in this study was a student of class IX.7 Junior High School Number 1 Bengkulu City school year 2020/2021 amounting to 33 learners. The data was collected by using the final cycle concept comprehension test form using the google form feature. The results showed that the application of online learning models during the Covid-19 pandemic through the Cloud X application and using power point media and learning videos could improve student learning outcomes. The increase in student learning outcomes can be seen from the average scores of students from cycle I to cycle II is: 76.90 ; 81.12 and classical learning completeness of students is $36.36 \% ; 78.79 \%$.
\end{abstract}

Keywords: Online Learning model,Learning using Cloud X, Learning Outcomes, the Covid-19 Pandemic.

\section{INTRODUCTION}

Education is an activity that is carried out to gain insight, knowledge and develop skills and attitudes that exist in each individual. Education is a concern for various parties as well as the government, one of which is by applying the 2013 curriculum that aims to prepare Indonesian people to have the ability to live as individuals and citizens who are faithful, productive, creative, innovative, and affective and able to contribute to the life of society, nation, state, and world civilization (Permendikbud, 2014:3). The focus of curriculum 2013 is the formation of attitudes, skills and knowledge for learners, and focusing more on the learning process is not just the result of the learning. The ability to implement the curriculum in 2013 can be through mathematics learning.

Mathematics is a lesson that is widely used in other scientific fields and exists at every level of education. In accordance with what is stated in UU No.20 of 2003 Article 37 Paragraph 1, that "Mathematics learning is one of the elements that become the basis in the development process of various scientific fields, such as in the fields of economics, science, technology, information, and communication, as well as other scientific fields". Mathematics is not just numbers or numbers that are not real, but mathematics is in life. Almost all human activities are related to mathematics. With mathematics, various life problems can be solved by mathematical thinking. Knowledge and experience of mathematics are gained by learners through mathematics learning activities in schools.

In 2020 Indonesia was hit by the Covid-19 outbreak,this outbreak not only hit Indonesia but also hit various parts of the world. According to WHO (2020), Covid-19 is an infectious disease caused by a group of SARS-COV2 viruses that was recently discovered in Wuhan, China, in December 2019 and spread throughout the world. The Covid-19 outbreak has impacted many areas 
including education. The increasing spread of the Covid-19 virus has led the Indonesian government to issue various policies related to handling the spread of the Covid-19 virus, one of which is government regulation No. 21 of 2020 on Large-Scale Social Restrictions, as a result of which the learning process in schools becomes hampered so that learning that was originally in school switches to distance learning or learning from home.

Distance learning systems use online learning models utilizing and using technologies, such as the use of google classroom applications, whatsapp groups, and zoom. Educators use a wide variety of learning media and applications to achieve learning goals while creating exciting and enjoyable learning. Math teachers at junior high school number 1 Bengkulu city use whatsapp group and google classroom applications to share materials, assignments, and monitor their students. WhatsaApp group is currently widely used by educators, students, and lecturers as a discussion forum that helps the implementation of distance learning during the covid-19 pandemic (Kusuma \& Hamidah, 2020:100). But in its implementation this application is only used to control learners, while the assignment, collection of tasks, and discussions are carried out through the google classroom application. Google classroom is a free web service, developed by Google to simplify creating, distributing, and assessing tasks without having to come face-to-face. In addition to the google classroom application,educators can share materials in the form of powerpoint, microsoft word, or pdf.

The use of whatsapp group and google classroom applications is still considered less effective because there is still a lack of response from students and the average learning outcomes of students who are still under minimum completeness criteria are less than 75 . Therefore, a solution is needed to improve student learning outcomes, namely a virtual meeting is needed using a video conference application so that students can hear explanations from educators and can discuss the material and difficulties experienced, one of which can use the zoom application.. Zoom meet is a conference face-to-face platform where educators and learners can directly interact as they meet in person (Kusuma \& Hamidah, 2020:101). Kusuma and Hamidah's research (2020) showed that the use of zoom webinars gave better results than the classes given whatsapp group treatment. This is in line with amelia's research results, et al (2020:8) that the online learning process that begins with handouts through google classroom, followed by explanation of materials using zoom meetings and assignments through google classroom shows the positive response of learners and the resilience of learners in high mathematics during the learning process. In addition, the results of analysis of math assignments of learners in online learning showed that 5 out of 6 students got a task score above the minimum completeness criteria . But in this study, researchers will use cloud x meeting application that uses the same use as zoom meeting. This cloud $\mathrm{x}$ meeting application has never been tried in mathematics subjects at junior high school number 1 Bengkulu city. The use of cloud $\mathrm{x}$ is because junior high school number 1 Bengkulu city has cooperated with telkomsel so that the maximum number of meeting participants is 500 peoples and the implementation of the meeting has no time limit. In addition junior high school number 1 Bengkulu city also strongly supports online learning by distributing quotas to its students. To support the process of learning through cloud $\mathrm{x}$, powerpoint slides are required to be displayed during meetings and to be shared in google classroom. This powerpoint should be made as attractive as possible so that the learners are interested and do not feel bored.

Learning through video conference turns out to have several disadvantages, including the material delivered can not be repeated and for students who are in locations with unstable signal strength complain of difficulty to join the meeting room to follow the learning process (Kusuma \& Hamidah, 2020:105). This darkness can be overcome by creating a learning video that will be uploaded on youtube. According to Purwanto and Rizki (2015:69) the learning video is a learning medium containing sounds, images, crackle, and text about learning materials that are packed briefly, densely, and clearly. This learning video can be watched by learners anytime and anywhere, so that students who do not follow the learning through cloud $\mathrm{x}$ can watch the learning video and 
the learners who follow the learning can repeat the lessons that have been learned. Various research results show that the use of learning videos can also improve the learning outcomes of learners. According to baharudin research (2014:96), hasil studied mathematics students in grade XI 3 SMA Negeri 1 Bajo experienced an increase that was previously in a very low category with an average of 33.75 from an ideal score of 100 to a moderate category with an average of 78.25 from an ideal score of 100 after being given a learning video. In addition, the results of Purwanto and Rizki's research (2015:76) showed that the average student learning outcome after being given a learning video was 84.33. It shows that learning videos can help in improving students' comprehension skills and learning outcomes.

\section{RESEARCH METHODS}

The type of research carried out is Classroom Action Research. Classroom Action Research is a study that has its own rules and procedures for learning activities in the form of an action, which is intentionally raised and occurs in a class (Mu'alimin, 2014:5). This research is focused on improving learners' learning outcomes with online learning models through the Cloud X application and using interesting learning powerpoints and videos.

The subjects of this study were students of grade IX.7 junior high school number 1 Bengkulu city which consisted of 33 people consisting of 17 men and 16 women. The study subjects were randomly selected based on consideration and approval from the school. After it was determined the researchers conducted a preliminary test understanding the concept first. The test results showed that class IX.7 has the potential to improve the understanding of the concept of learners well. Class Action Research (PTK) consists of 2 cycles. In each cycle, there are 4 stages, namely: (1) Planning; (2) Acting; (3) Observing; (4) Reflecting described as follows:

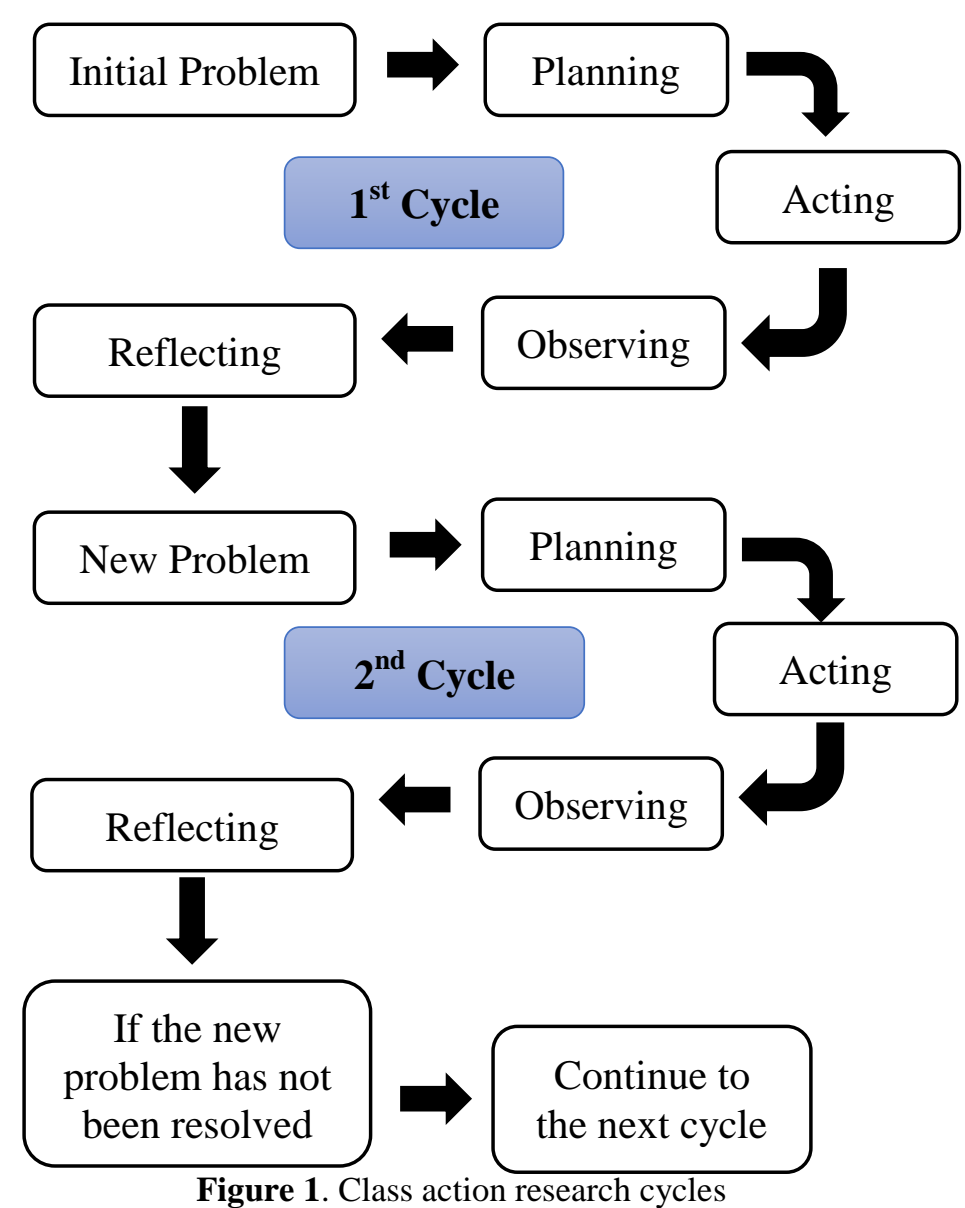


After the implementation of learning using online learning models, students are given the final test I to find out the completeness of learners' learning outcomes and used as a reference for improvement to carry out cycle II. After the second cycle, students are given the Final II test to determine the completeness of the learner's learning outcomes and will be used as a comparison between cycle I and cycle II.

The completion of learners' learning outcomes can be calculated by dividing the number of students who complete the study by the number of all learners. The criteria for mathematics learning for students in grade IX.7 junior high school number 1 Bengkulu city can be stated as follows:

a) individual completion, a learner is said to be complete if it has reached a $\geq 75$ out of a maximum value of 100 .

b) classical completion, a class is said to be complete if there is a minimum of $75 \%$ that has reached $\mathrm{a} \geq 75$ out of a maximum value of 100 .

$$
\mathrm{p}=\frac{\sum \text { students who have thoroughly studied }}{\sum \text { students }} \times 100 \%
$$

\section{RESULTS AND DISCUSSION}

Learners' learning outcomes are obtained from the test results given at the end of learning in cycle I and the end of learning in cycle II. This test was tested through google form and followed by 33 students from grade IX.7 junior high school number 1 Bengkulu city school year 2020/2021. The learning outcomes of learners in cycle I and cycle II have improved which can be seen in the following Table 1 and Figure 2:

Table 1. Learner Learning Outcomes and Classical Learning Completedness

\begin{tabular}{ccccc}
\hline Cycle & $\begin{array}{c}\text { average } \\
\text { value }\end{array}$ & $\begin{array}{c}\text { The number of } \\
\text { participants in } \\
\text { the complete } \\
\text { study }\end{array}$ & $\begin{array}{c}\text { Classical } \\
\text { Learning } \\
\text { Completedness }\end{array}$ & Description \\
\hline 1 & 76,90 & 12 & $36,36 \%$ & $\begin{array}{c}\text { Not Yet } \\
\text { Achieved }\end{array}$ \\
\hline 2 & 81,12 & 26 & $78,79 \%$ & Reached \\
\hline
\end{tabular}

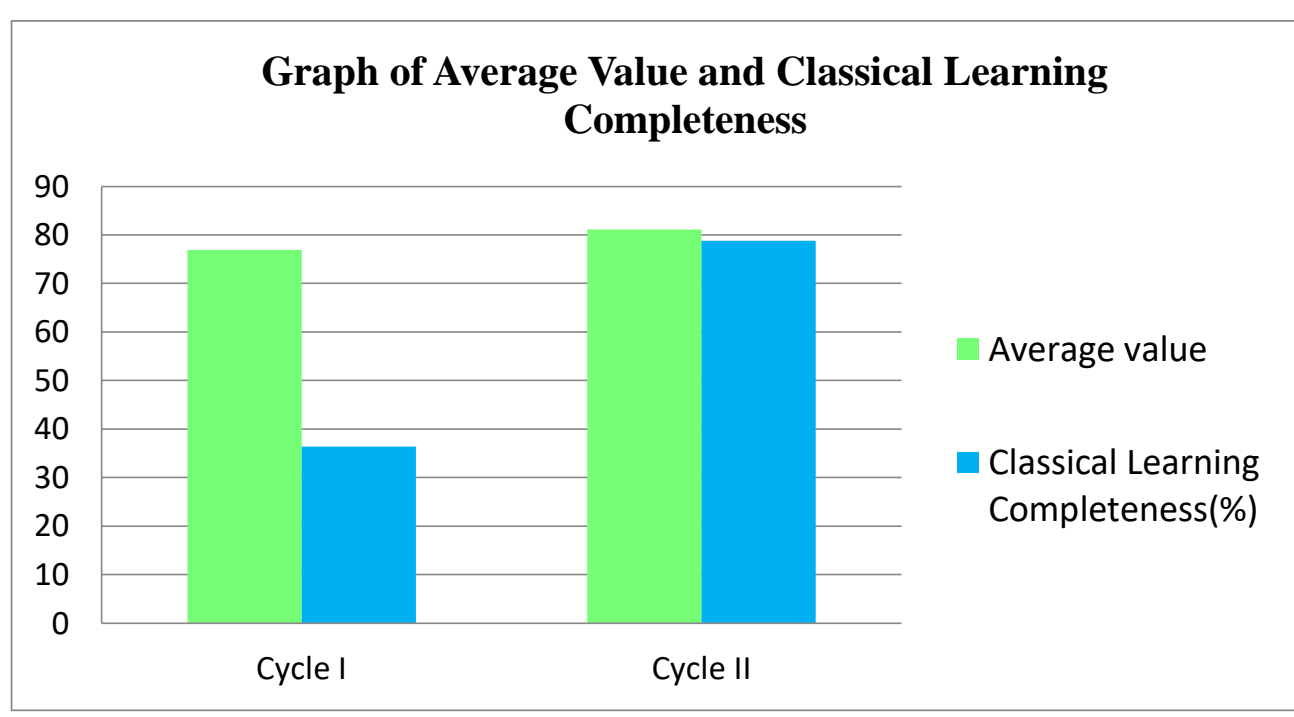

Figure 2. Students Learning Outcomes and Classical Learning Completeness Conclusions 
In the first cycle, teachers provide material explanations and conduct question and answer questions with students in cloud $x$ rooms that have been created as many as two meetings. It is also shared powerpoint in google classroom and learning videos on youtube so that students can repeat the material that has been submitted. The material discussed in cycle I is the quadratic equation.

At the beginning of the lesson the teacher greets the learners, prays, and performs attendance through the Cloud $\mathrm{x}$. The teacher conducts an aperception activity by conveying the purpose and benefits of studying the material. The teacher also asked the students if they already knew and read the material that would be learned that day. The teacher explained to the learner about the quadratic equation accompanied by displaying the material in the power points in cloud $\mathrm{x}$ room. Powerpoint slides displayed in cloud $\mathrm{x}$ room are the same as those shared in google classroom the day before the learning implementation. There is also a question and answer process about the examples of questions discussed. To increase the motivation of learners to be more active, researchers will appreciate students who dare to answer questions that have been given by recording their names and giving applause or praise. At the end of the lesson the teacher asked the learner to conclude the material and then the conclusion will be reinforced by the researcher. Teachers also give tests at the end of cycle 1 to learners in google form format to see the learners' learning results.

The learning results of learners in the first cycle showed that the average value of learners was 76.90 , but there were only 12 learners or $36.36 \%$, students who got a score of $\geq 75$ and 21 learners or $63.64 \%$ of students who got a score $<75$. Based on the data and referring to the indicators of learning success, it can be concluded that the learning results from the first cycle have not achieved the expected goal, namely $\geq 60 \%$ of learners get a score of $\geq 75$. Therefore, there needs to be improvement in learning which includes creating two different powerpoint materials to share in google classroom the day before the learning process and to be displayed during the learning process. Powerpoint displayed during the learning process contains a summary of materials from powerpoints that have been shared and contains more displays of questions that will be discussed together with the learners, so that the learners are more interested, feel challenged, and trained in working on questions related to the material.

In the second cycle, learning is done in the same way that is by providing material explanations and conducting question and answer with students in cloud-x rooms that have been made as many as two meetings. It is also shared powerpoint in google classroom and learning videos on youtube so that students can repeat the material that has been submitted. But what's different is that the powerpoint slides displayed in cloud $\mathrm{x}$ room are different from the slides that have been shared on google classroom. The shared slide contains material and some sample discussions while the slide is displayed containing a summary of material from the previous slide and new questions that will be discussed together. The material discussed in cycle II is the quadratic function.

At the beginning of learning the teacher greets students, says prayers, and makes attendance through the Cloud-x application. The teacher performs apperception activities by conveying the objectives and benefits of studying the material. The teacher also asks students whether they already know and read the material that will be studied that day. The teacher explains to students about quadratic equations accompanied by displaying material in the form of power points in cloud $\mathrm{x}$ room. The powerpoint slides displayed in cloud $\mathrm{x}$ room are different from the slides shared in google classroom the day before the lesson. There is also a question and answer process regarding the questions that have been prepared on PowerPoint. The teacher gives 5 minutes so that students look for answers and those who can answer are welcome to answer. After that the answer is responded to by other students and discussed together. If there is no response from students, the teacher will call the students randomly and ask what the answer is. This was done because there were some students who did not dare to answer. However, if they cannot answer, the teacher asks about the difficulties they are experiencing. To increase student motivation to be more active, researchers will appreciate students who dare to answer questions that have been given or provide 
responses by writing down their names and giving applause or praise. In teaching the graph of quadratic functions, the teacher also uses the aid of the geogebra application to prove whether the students' pictures are true or false. At the end of the lesson the teacher asks students to conclude the material which then the conclusion will be reinforced by the researcher. The teacher also provides a test at the end of cycle II to students in google form format to see student learning outcomes.

The results of learning of learners in the second cycle showed that the average value of learners is 81.12 with 26 learners or $78,79 \% \%$, students who get scores of $\geq 75$ and 7 learners or $21.21 \%$ of students who get a score $<75$. Based on the data and referring to the indicators of learning success, it can be concluded that the learning results from cycle II have achieved the expected goal, namely $\geq 60 \%$ of learners get a score of $\geq 75$. This increase occurs because learners are more interested in learning, more active and better understand the material and various forms of problems.

\section{CONCLUSION}

Based on the results of research that has been conducted in grade IX.7 junior high school number 1 Bengkulu city school year 2020/2021, it can be concluded as follows:

1. Learning with online learning models through the cloud $x$ application and using powerpoints that discuss a lot of problems, on the subject of equations and quadratic functions can improve the learning outcomes of learners. The use of geogebra application assistance on the subject of quadratic functions can improve learners' understanding of quadratic function graphs. This can be seen from the average value of learners who experienced an increase from cycle I to cycle II, namely 76.90 to 81.12 .

2. Learning with online learning models through cloud $x$ applications and using interesting learning powerpoints and videos can increase the completeness of classical learning by $36.36 \%$ in the first cycle to 78.79 in the second cycle .

\section{REFERENCES}

Amelia, R., Kadarisma, G., Fitriani, N., \& Ahmadi, Y. (2020). The effect of online mathematics learning on junior high school mathematic resilience during COVID-19 pandemic. Journal of Physics: Conference Series, 1657(1). https://doi.org/10.1088/1742-6596/1657/1/012011.

Aqib, Z.,Diniati, E.,Jaiyaroh, S. \& Khotimah, K. 2016. Penelitian Tindakan Kelas untuk Guru SD, $S L B$ dan TK. Bandung: Yrama Widya.

Baharuddin, I. (2014). Efektivitas Penggunaan Media Video Tutorial Sebagai Pendukung Pembelajaran Matematika Terhadap Minat Dan Hasil Belajar Peserta Didik Sma Negeri 1 Bajo Kabupaten Luwu Sulawesi Selatan. Jurnal Nalar Pendidikan, 2(2), 247-255.

Kusuma, J. W., \& Hamidah, H. (2020). Perbandingan Hasil Belajar Matematika Dengan Penggunaan Platform Whatsapp Group Dan Webinar Zoom Dalam Pembelajaran Jarak Jauh Pada Masa Pandemik Covid 19. JIPMat, 5(1). https://doi.org/10.26877/jipmat.v5i1.5942.

Mu'alim \& Cahyadi. 2014. Penelitian Tindakan Kelas Teori dan Praktik. Pasuruan: Ganding Pustaka.

Permendikbud No. 58 Tahun 2014 Tentang Kurikulum 2013 Sekolah Menengah Pertama/Madrasah Tsanawiyah. 
Purwanto, Y., \& Rizki, S. (2015). Pengembangan Bahan Ajar Berbasis Kontekstual Pada Materi Himpunan Berbantu Video Pembelajaran. AKSIOMA Journal of Mathematics Education, 4(1), 67-77. https://doi.org/10.24127/ajpm.v4i1.95

Sartika, Ferenc F. (2020). Peningkatan Kemampuan Pemahaman Konsep Matematika Peserta Didik Kota Bengkulu Melalui Model Pembelajaran Kooperatif Tipe TTW. Jurnal Penelitian Pembelajaran Sekolah. Volume: 4, nomor: 1.

Undang-Undang Republik Indonesia Nomor 20 Tahun 2003 Tentang Sistem Pendidikan Nasional.

WHO. (2020). What is Covid-19?. Taken from who.int/emergencies/diseases/novel-coronavirus2019/question-and-answers-hub/q-a-detail/coronavirus-disease-covid-19 [Website]. 